\title{
Tradisi Gebug Ende Bentuk Ritual Memohon Hujan Pada Masyarakat Seraya Di Desa Patas Kabupaten Buleleng
}

\author{
Dewa Nyoman Sucita \\ STKIP Agama Hindu Singaraja, Singaraja, Indonesia \\ Email: stkipagamahindu@yahoo.com
}

\begin{abstract}
Abstrak
Penelitian ini bertujuan untuk mengetahui berbagai hal ikhwal terkait dengan pementasan Gebug Ende yang dilaksanakan dalam kaitannya dengan memohon hujan pada masyarakat Seraya, di desa Patas, Kecamatan Gerogak, Kabupaten Buleleng. Untuk mencapai tujuan itu digunakan beberapa metode, antara lain metode pendekatan purposive sampling dan snowball sampling, metode pengumpulan data, wawancara dan pencatatan dokumen dan metode analisis data kualitatif. Di samping itu, ditunjang pula oleh teori relegi dari Koentjaraningrat. Berdasarkan hal tersebut hasil yang diperoleh sebagai berikut: 1). Lara belakang pementasan tradisi Gebug Ende pada upacara memohon hujan adalah sejarah kemenangan prajurit-prajurit Karangasem yang berasal dari desa Seraya berkat adanya hujan lebat pada saat perang melawan prajurit Seleparang, sehingga setiap kekeringan/kemarau, dilaksanakan ritual mememohon hujan selalu disertai dengan permainan perang-perangan yang disebut Gebug Ende. 2). Upakara yang mengiringi pementasan tradisi Gebug Ende di desa Patas, sangat sederhana, yakni berupa sesajen atau banten. Banten yang digunakan sangat sederhana terdiri dari beberapa jenis banten saja, yaitu canang raka, daksina, dan segehan nasi hitam putih.3). Tempat pementasan tradisi Gebug Ende tidak harus mencari tempat suci, melainkan tepat atau areal yang luas dan datar yang berada di wilayah atau kawasan desa Patas. Oleh karena itu, tempatnya bisa berpindah-pindah. 4). Pakaian dan perlengkapan peserta Gebug Ende di desa Patas hanya menggunakan (21). Destarlikat kepala berwarna merah sebagai lambang keberanian, (2). Kain/kamen, dipakai dengan mebulet ginting dan (3). Saput poleng, (hitam putih) sebagai lambang rwa bhineda (baik buruk). 5).Tata cara pementasan tradisi Gebug Ende di desa Patas dipimpin oleh seorang saya, yang diawali dengan ritual keagamaan. Selanjutnya saya menyampai aturan permainan.
\end{abstract}

Kata Kunci: Gebug Ende, Ritual.

\section{PENDAHULUAN}

Upacara yang dilaksanakan dalam agama Hindu ada yang terkait dengan alam lingkungan, kondisi dan situasi yang dihadapi oleh umatnya. Upacara yang dilaksanakan umat yang berada di pinggir laut, jenis dan wejudnya akan berbeda dengan upacara yang dilaksanakan oleh umat yang bertempat tinggal di pedalaman atau di pegungan. Demikian pula upacara yang dilaksanakan oleh umat pada waktu musim penghujan berbeda dengan upacara yang dilaksanakan pada musim kemarau. Upacara yang dilaksanakan petani di sawah pada waktu ada hama akan 
berbeda dengan upacara yang dilaksanakan pada saat panen raya. Singkatnya alam lingkungan dan kondisi yang dihadapi oleh umat Hindu berdampak pada jenis dan bentuk upacara yang dilaksanakan.

Salah satu upacara agama Hindu yang dilaksanakan oleh masyarakat Seraya di desa Patas adalah upacara memohon hujan. Upacara ini dilaksanakan pada musim kemarau atau musim kering. Kita ketahui bahwa Kecamatan Gerogak berada pada daerah dataran tinggi yang kering, di mana para petaninya hanya menghandalkan curah hujan untuk mengairi tanah perkebunannya. Umumnya para petani menanam jagung, kacang-kacangan, ketela dan lain-lain pada musim penghujan. Upacara memohon hujan ini disaertai dengan sebuah tradisi masyarakat yang mereka bawa dari tanah leluhurnya desa Seraya Karangasem. Tradisi yang dimaksud adalah tradisi Gebug Ende. Setiap upacara memohon hujan selalu disertai dengan tradisi Gebug Ende ini, sehingga lama-kelamaan tradisi Gebug Ende ini identik dan menjadi bagian dari upacara memohon hujan di desa Patas.

Bagi masyarakat Buleleng, tradisi Gebug Ende yang dirangkai dengan uapacara agama Hindu merupakan sesuatu yang asing. Pada umumnya upacara agama Hindu selalu dikaitkan dengan seni sakral baik seni tari, seni tabuh, seni suara (Dharmagita). Di daerah Buleleng hanya di desa Gerogak saja yang dijumpai sebuah upacara agama yang dikaitkan dengan seni propan seperti tradisi Gebug Ende ini. Hal inilah yang menarik untuk diteliti dan dikaji dalam sebuah penelitian dengan judul Tradisi Gebug Ende Bentuk Ritual Memohon Hujan Pada Masyarakat Seraya Di Desa Patas Kecamatan Gerogak Kabupaten Buleleng

\section{Tujuan Penelitian}

Berdasarkan beberapa masalah di atas, maka yang menjadi tujuan penelitian ini adalah sebagai berikut.

1. Untuk mengetahui yang melatarbelakangi setiap upacara memohon hujan di desa Patas disertai dengan pementasan tradisi Gebug Ende.

2. Untuk mengetahui upakara yang digunakan dalam upacara memmohon hujan dan pementasan tradisi Gebug Ende di desa Patas.

3. Untuk mengetahui tempat pementasan tradisi Gebug Ende di desa Patas.

4. Untuk mengetahui kostim atau pakaian yang digunakan oleh peserta dalam pementasan tradisi Gebug Ende di desa Patas.

5. Untuk mengetahui tata cara pementasan tradisi Gebug Ende di desa Patas

Berbicara masalah agama atau sistem keyakinan atau masalah upacara, menurut Koentjaraningrat ada lima komponen yang tidak dapat ditinggalkan, yaitu: 1) Sistem keyakinan, 2) waktu upacara, 3) tempat upacara, 4) pendukung upacara, dan 5) peralatan upacara. Kelima unsur pokok itu merupakan satu kesatuan yang tidak dapat dipisah-pisahkan.

\section{Sistem Keyakinan}

Sistem keyakinan dalam suatu religi berwujud suatu pikiran dan gagasan manusia yang menyangkut keyakinan dan konsepsi manusia tentang sifat-sifat Tuhan, tentang wujud dan alam gaib tentang terjadinya alam-alam dan dunia, akhirat.Tentang wujud dan ciri-ciri kekuatan sakti, roh nenek moyang, roh alam, dewa-dewa, roh jahat, hantu dan mahluk lainnya. Kecuali itu sistem keyakinan juga menyangkut sistem nilai dan sistem norma keagamaan, ajaran kesusilaan dan 
ajaran doktrin religi lainnya yang mengatur tingkah laku manusia. Sistem keyakinan tersebut biasanya terkandung dalam kesusastraan suci, baik yang sifatnya tertulis maupun yang tidak tertulis. (Koentjaraningrat, $1990: 240$ ).

Pada buku Upadeça disebutkan Agama Hindu mempunyai kerangka dasar yaitu : 1) Tattwa (Filsafat), 2) Susila (Etika), 3) Upakara (Ritual). Dan ketiga-tiganya itu merupakan satu kesatuan yang bulat yang tidak dapat dipisah-pisahkan. Disamping Agama Hindu mempunyai kerangka dasar juga mempunyai kepercayaan mutlak yang disebut dengan Panca Sradha, yaitu : 1) Percaya dengan adanya Ida Sang Hyang Widhi, 2) Percaya dengan adanya Atman, 3) Percaya dengan adanya Hukum Karma Phala, 4) Percaya dengan adanya Samsara, dan 5) Percaya dengan adanya Moksa. (Upadeça, $1978: 13-14)$.

Waktu Upacara

Penentuan waktu merupakan hal yang cukup penting dalam suatu perbuatan keagamaan. Salah menentukan waktu mengakibatkan tidak tercapainya apa yang menjadi keinginan dan tujuan upacara. Saat-saat yang genting dan gawat penuh dengan bahaya gaib biasanya saat yang sangat tepat dilaksanakan upacara sebagai upaya manusia untuk menetralisir akibat yang akan ditimbulkan oleh kondisi yang tidak baik itu. Pada buku Beberapa Pokok Antropologi Sosial disebutkan bahwa waktu-waktu serupa itu dirasakan sebagai saat-saat yang genting, gawat dan bisa banyak membawa bahaya gaib, yang akan membawa kesengsaraan dan penyakit kepada manusia, binatang maupun tumbuh-tumbuhan. Bahaya gaib harus ditolak dan dijaga dengan berbagai jenis upacara, dan saat itu orang harus erat hubungannya dengan dunia gaib. (Koentjaraningrat, $1990: 225)$.

Sebagai yang telah diuraikan di depan, bahwa umat Hindu di dalam hidup dan kehidupannya sehari-hari selalu diliputi oleh pelaksanaan yadnya yang diiringi berbagai bentuk, waktu dan jenis upacaranya. Pelaksanaan Yadnya yang berjenisjenis itu tentang tujuannya tiada menyimpang dari prinsip-prinsip inti ajaran Dharma. (Putra dan Negara, $1996: 31$ ).

\section{Tempat Upacara}

Tempat upacara yang keramat biasanya terletak di pusat Desa, di dalam lingkungan rumah tangga, di kuburan, di sawah atau di ladang, di tepi pantai, di perempatan jalan dan sebagainya, pokoknya semua tempat dimana orang merasakan dunia gaib, biasanya menjadi tempat keramat untuk melakukan upacara keagamaan. Tempat upacara yang keramat di suatu tempat yang dikhususkan dan yang tidak boleh didatangi orang yang tidak berkepentingan, malahan mereka yang memiliki kepentingan tidak boleh sembarangan di suatu tempat upacara. Mereka harus berhati-hati dan memperhatikan berbagai macam larangan dan pantangan. (Koentjaraningrat, 1982 : 242).

\section{Pelaku / Pendukung Upacara}

Dalam setiap upacara keagamaan bagaimanapun tingkatanya akan melibatkan orang-orang, baik secara langsung ataupun tidak demi kelancaran dan cepatnya tercapai suatu tujuan. Orang-orang yang terlibat bisa sebagai individu ataupun kelompok-kelompok sosial keagamaan yang kesemuanya merupakan masyarakat pendukung dan pelaku upacara keagamaan itu sendiri, serta di dalam keterlibatannya bisa sebagai peserta biasa, pelaksana dan bisa sebagai pemimpin upacara. Dibia (tt. 4) mengatakan orang-orang yang melakukan upacara misalnya 
kelompok kerabat dalam ikatan satu keluarga besar atau kelompok kekerabatan yang lebih luas, yang di pimpin oleh Pendeta, Pemangku atau orang yang dianggap suci.

Di dalam buku Palinggih di Pemerajan disebutkan bahwa: upacara keagamaan itu dilakukan oleh tiga komponen yang tidak dapat dipisahkan yang disebut dengan Tri Manggalaning Yadnya yaitu: Sang Sadhaka yaitu orang yang memimpin dan menyelesaikan upacara keagamaan secara ritual, Sang Widya/Sarati yaitu Tukang banten yaitu orang yang membuat dan mengatur babanten upakara yadnya dan Sang Yajamana yaitu orang yang melakukan atau orang yang mempunyai upacara keagamaan. (Wiana, 1989:23).

Tentang kelompok-kelompok keagamaan sebagai pendukung upacara keagamaan di dalam buku adat-istiadat diuraikan sebagai berikut: pada masyarakat Bali kelompok-kelompok keagamaan yang berbentuk kekeluargaan inti, kelompok kekerabatan, dan kesatuan hidup setempat mengkonsepsikan kebudayaan dan mengaktifkan jenis-jenis upacara yang merupakan bagian dari sistem kepercayaan dan sistem upacara dari kelompok yang lebih luas yaitu masyarakat Bali. (Departemen Pendidikan dan Kebudyaan, 1985: 92).

\section{Peralatan Upacara}

Peralatan upacara merupakan alat-alat yang dipakai dalam hal menjalankan upacara-upacara keagamaan.Alat-alat upacara yang lazim digunakan adalah patung-patung yang mempunyai fungsi sebagai lambang Tuhan atau roh nenek moyang yang menjadi tujuan upacara. Adapun suatu golongan benda-benda yang dipakai secara universal dalam upacara keagamaan adalah bunyi-bunyian karena suara, nyanyian dan musik merupakan suatu unsur yang sangat penting dalam upacara keagamaan. (Koentjaraningrat, 1982 : 245). Alat dan sarana upacara yang digunakan dalam kegiatan keagamaan pada umumnya: patram, puspam, phalam, toyam, yaitu:daun-daunan,bunga,buah-buahan dan air. Pudja,(1982:220),yang ditata dalam bentuk banten atau upakara berfungsi sebagai simbol-simbol Hyang Widhi, dan sebagai alat konsentrasi. Sedangkan menurut Surayin,(1993:7), alat dan sarana prasarana upacara juga dapat berupa patung dewa-dewa, topeng leluhur dan bunyi-bunyian serta tari-tarian.

Mengenai alat-alat dan sarana upacara keagamaan sering pula disebut dengan upakara yang mepunyai pengertian serta fungsi sebagai: a). Upakara adalah merupakan suatu wujud cetusan hati dari umat Hindu untuk menyatakan rasa terima kasihnya kehadapan Ida Sang Hyang Widhi Wasa dengan segala menefestasi-Nya, khususnya bagi umat Hindu yang menempuh jalan mencari Tuhan dengan cara Bakthi Marga, sebab bagi umat Hindu yang sudah tinggi kekuatan batinnya mereka mungkin tidak perlu menggunakan upakara/banten untuk menghubungkan diri dengan Tuhan, tetapi melalui Yoga Samadhi. b). Upakara adalah merupakan dan alat konsentrasi pikiran untuk memuja Ida Sang Hyang Widhi Wasa dengan segala manefestasi-Nya. Misalnya kalau membuat banten, maka pada saat mulai mengambil alat perlengkapannya, pikiran sudah mulai teringat/terbayang pada pura atau keadaan pada setiap banten yang akan dipersembahkan kehadapan Ida Sang Hyang Widhi Wasa, maka banten adalah sarana cetusan bakti umat Hindu kepada Tuhan Yang Maha Esa atau Ida Sang Hyang Widhi Wasa dengan segala manefestasi-Nya. c). Upakara(banten) adalah merupakan perwujudan dan tapakan daripada ida Sang Hyang widhi wasa atau dewa-dewa manefestasinya. Misalnya daksina linggih, panyeneng, dan sebagainya. 
Sesungguhnya disamping sebagai persembahan atau tanda terimakasih, maka banten mempunyai bukti tertentu antara lain: (1). Sebagai alat kosentrasi untuk memuja Ida Sang Hyang Widhi Wasal Tuhan Hyang Maha Esa, misalnya: orang yang sedang membuat (nanding) banten telah membayangkan kemana akan dibawa atau kepada siapa akan dipersembahkan banten tersebut. Oleh karena itu, wajarlah bila orang tua menasehati agar pada waktu membuat banten tidak melontarkan kata-kata yang kurang baik, marah-marah, menggaruk-garuk kepala, dan lain-lain yang dianggap kurang sopan. 2) sebagai perwujudan dari Ida Sang Hyang Widhi dan manifestasi-Nya atau orang yang diupacarai, misalnya: Kwangen, Daksina Palinggih, Lingga, Sanggah Urip, Puspa (sekar), dan sebagainya. 3) Sebagai alat penyucian, misalnya: Prayascitha, Durmanggala, Byakala, dan lainlainya. ( Masputra, 1982:3).

Upakara atau banten yang dipergunakan dalam suatu upacara keagamaan pada umumnya lebih banyak material. Agar suatu upacara agama dapat menjangkau pelaksanaannya oleh seluruh lapisan masyarakat Hindu, maka dipakailah pedoman Nista, Madya, dan Utama. Demikian misalnya hanya dengan sebuah dupa yang menyala ditangan dan pikiran yang hening seorang umat Hindu mengucapkan doa, memuja kehadapan Sang Hyang Widhi beserta ManifestasiNya, itu sudah termasuk beryadnya.

\section{METODE PENELITIAN}

Dalam menuntaskan penelitian ini, peneliti menggunakan metode penentuan informan, metode pengumpulan data dan metode analisis data. Teknik penentuan informan yang digunakan adalah purposive sampling dan snowball sampling. Teknik purposive sampling adalah teknik penentuan informan (sumber data) dengan pertimbangan tertentu, misalnya orang tersebut yang dianggap paling tahu tentang apa yang diharapkan oleh peneliti. Sedangkan snowball sampling adalah teknik penentuan informan (sumber data) yang pada awalnya berjumlah sedikit, lama-lama menjadi besar.

Dalam penelitian ini, informan yang dipilih adalah tokoh-tokoh masyarakat Desa Patas yang berkompeten, seperti: tokoh agama, tokoh masyarakat, dan para pemuda Patas yang sudah pernah mengikuti permainan Gebug Ende ini.

Dalam mengumpulkan data digunakan dua teknik, yaitu wawancara dan pencatatan dokumen. Wawancara yang digunakan peneliti adalah wawancara tak berstruktur. Wawancara tak berstruktur dipilih dengan alasan peneliti belum mengetahui secara pasti data apa yang akan diperoleh sehingga peneliti lebih banyak mendengarkan apa saja yang diceritakan oleh responden. Berdasarkan analisis terhadap berbagai jawaban yang telah diperoleh dari responden, maka peneliti dapat mengajukan berbagai pertanyaan lanjutan yang lebih terarah pada suatu tujuan. Pertanyaan lanjutan itu bertujuan untuk mempertajam data yang diperoleh sehingga menjadi data yang kredibel.

Studi dokumen merupakan pelengkap dari penggunaan metode observasi dan wawancara dalam penelitian kualitatif. Hasil penelitian dari hasil wawancara dan observasi akan lebih kredibel atau dapat dipercaya bila didukung dengan dokumen. Dokumen yang di-tampilakan untuk mendukung penelitian ini adalah berupa catatan, 
peraturan, dan lainnya yang di-anggap sebagai dokumen pen-dukung data penelitian.

Berdasarkan dua teknik pengumpulan data tersebut peneliti menggunakan teknik triangulasi. Teknik pengumpulan data dengan triangulasi adalah teknik pengumpulan data yang bersifat menggabungkan dari berbagai teknik pengumpulan data dan sumber data yang telah ada. Teknik ini digunakan dengan alasan di samping dapat mengumpulkan data juga sekaligus dapat menguji kredibilitas data. Menggunakan teknik triangulasi dalam pengumpulan data akan memperoleh data yang lebih konsisten, tuntas, dan pasti, serta akan lebih meningkatkan kekuatan data (Sugiyono, 2007:241).

Data yang diperoleh harus dapat memberikan jawaban terhadap masalah yang dirumuskan. Dalam penelitian kualitatif, data yang diperoleh berasal dari berbagai sumber dengan menggunakan teknik pengumpulan data yang bermacammacam dan dilakukan secara terus menerus mengakibatkan variasi data tinggi sekali. Untuk memudahkan analisis, data yang diperoleh perlu diolah terlebih dahulu karena data tersebut belum teratur, belum diklasifikasikan atau belum dikategorikan. Aktivitas dalam analisis data terdiri dari 1) Data Reduction atau merangkum data, 2) Data Display atau menyajikan data, dan 3) Conclusion drawing/verification yaitu penarikan kesimpulan atau verifikasi.

\section{HASIL DAN PEMBAHASAN}

Dalam Kamus Bahasa Bali disebutkan, istilah Gebug Ende terdiri dari dua kata, yaitu Gebug dan Ende. Gebug berarti pukul dan Ende berarti perisai dari kulit dalam permainan megebug (1990:188). Secara etimologi, kita dapat memahami pengertian Gebug Ende pada dasarnya sebuah permainan yang dilakukan oleh dua orang/kelompok yang saling menyerang atau memukul dan masing-masing membawa pemukul yang terbuat dari rotan dengan panjang 1,5 meter dan ende yang berbentuk bulat dari kulit sapi dengan lebar kurang lebih $65 \mathrm{~cm}$ untuk menakis serangan lawan.

Tradisi Gebug Ende yang dilaksanakan oleh masyarakat desa Patas dikenal pula dengan sebutan Gebug Seraya. Hal ini disebabkan karena tradisi ini dilaksanakan oleh masyarakat Patas yang berasal dari desa Seraya Barat, Kabupaten Karangasem. Artinya, tradisi Gebug Ende ini awalnya dilaksanakan oleh masyarakat di tanah kelahirannya dan setelah mereka pindah dan menetap menjadi penduduk desa Patas, mereka tetap melaksanakan tradisi Gebug Ende ini sehingga masyarakat desa Patas yang lain atau penduduk asli desa Patas menyebut tradisi Gebug Ende ini dengan sebutan Gebug Seraya.

Tradisi Gebug Ende pada dasarnya sebuah permainan atau pertandingan antar peserta, di mana antar peserta saling menyerang atau memukul dengan menggunakan rotan dan yang diserang bertahan atau menangkis dengan menggunakan ende. Oleh karena itu, para pemain atau pesertanya semuanya lakilaki baik anak-anak remaja maupun dewasa, yang dikenal dengan teruna-teruna. Mengingat Gebug Ende sebuah permainan dan dipentaskan dalam ritual keagamaan, maka banyak menimbulkan pertanyaan, maka di bawah ini akan diuraikan hal ikhwalnya sehingga dapat dipahami dengan benar oleh masyarakat. 


\section{Latar Belakang Pementasan Tradisi Gebug Ende dalam Upacara Memohon Hujan}

Di atas sudah disebutkan bahwa tradisi Gebug Ende ini dilaksanakan oleh masyarakat Patas yang berasal dari desa Seraya, Kabupaten Karangasem. Kebiasaan masyarakat semasih di tempat asalnya setiap memhon hujan selalu disertai dengan permainan Gebug Ende ini, dan kebiasaan ini mereka tetap bawa dan laksanakan walaupun mereka telah tinggal di wilayah Gerogak Kabupaten Buleleng. Asal-usul mengapa setiap memohon hujan selalu dipentaskan Gebug Ende ada latar belakang ceritanya.

Diceritakan bahwa pada zaman dahulu masyarakat Seraya sebagian besar kuat-kuat dan kebal-kebal terhadap senjata tajam, maka masyarakat ini yang dipilih menjadi prajurit andalan kerajaan Karangasem berjumlah 40 orang yang dikenal dengan sebutan Bala Petangdasa. Di samping itu, yang juga dipilih menjadi prajurit kerajaan Karangasem adalah masyarakat Bubug yang ahli pengobatan dan masyarakat Angantelu yang sangat pemberani. Prajurit yang berasal dari tiga desa inilah yang ditugaskan raja menyerang kerajaan Seleparang, Lombok Barat.

Orang-orang yang masuk menjadi kelompok prajurit dipilih dan dites dalam sebuah sangkepan/rapat dalam bentuk tes kekebalan. Sang calon prajurit menjepit duri pandan di ketiaknya, lalu ditarik. Apabila sang calon tidak luka, maka yang bersangkutan lolos tahap pertama. Tes kedua dilaksanakan dengan membelah buah pinang di atas paha. Apabila pinang terbelah menjadi dua dan paha sang calon tidak luka berarti yang bersangkutan lolos menjadi pasukan prajurit. Dan senjata yang akan digunakan perang pun dipilih dan diseleksi. Senjata dites dengan menebangkan bambu dan kayu-kayu yang keras. Apabila senjata itu tetap kuat dan tajam, maka senjata itu layak digunakan sebagai senjata perang.

Pada saat perang berlangsung dengan hebat dan sengitnya antara prajurit kerajaan Karangasem dengan prajurit kerajaan Seleparang, hujan turun dengan lebat. Para prajurit Karangasem merasa dengan turunya hujan lebat merasa mendapat bantuan dan waranugraha dari Hyang Widhi, karena dengan turunya hujan lebat lebih memudahkan mengalahkan musuh. Dan itu terbukti, mereka dapat mengalahkan prajurit lawan. Setelah perang beraakhir, para prajurit dari ketiga desa ini, kembali ke desa masing-masing. Sesampainya Para prajurit Seraya di desanya, ternyata terjadi bencana kekeringan. Para penduduk kesulitan mendapatkan air, baik untuk kehidupan sehari-hari maupun untuk keperluan pertanian dan perkebunan. Oleh karena keberhasilan mereka memenang peperangan dengan prajurit Seleparang atas bantuan hujan lebat, maka para prajurit Seraya, berinisiatif melaksanakan upacara memohon hujan kepada Hyang Widhi disertai dengan permainan peperangan, yang disebut dengan Gebug Ende. Maka sejak saat itu setiap upacara memohon hujan selalu disertai dengan permainan perang-perangan. Oleh karena, setiap musim kemarau ritual ini selalu diadakan maka Gebug Ende menjadi mentradisi di kalangan masayarakat Seraya. Tradisi ini tetap pula dilaksankan oleh masyarakat Seraya yang merantau dan menetap di desa Patas, Kecamatan Gerogak, Kabupaten Buleleng.

\section{Upakara yang Digunakan dalam Tradisi Gebug Ende dan Memohon Hujan}

Pada umumnya setiap pementasan tari Bali selalu disertai dengan upacara keagamaan. Lebih-lebih tari Bali yang tergolong tari sakral, tentu menggunakan upacara yang bersifat khusus dan menggunakan upakara atau banten yang bersifat 
khusus pula. Mengingat pementasan Gebug Ende ini terkait dengan permohonan hujan kepada Hyang Widhi, Tuhan Yang Mahaesa, maka pementasannya pun menggunakan upacara dan menggunakan beberapa jenis banten. Banten yang digunakan sangat sederhana terdiri dari beberapa jenis banten saja, yaitu canang raka, daksina, dan segehan nasi hitam putih. Dan yang memimpin atau mengantarkan upakara atau banten yang digunakan pada pementasan Gebug Ende ini adalah para pemangku khayangan tiga yang dituur saat pementasan tersebut. Artinya, pemangku yang mengantarkan upacara itu bisa pemangku desa, pemangku puseh atau pemangku Dalem.

\section{Tempat Pementasan Tradisi Gebug Ende}

Pementasan Gebug Ende di desa Patas dirangkaikan dengan sebuah permohonan kepada Hyang Widhi, Tuhan Yang Mahaesa, agar Beliau melimpahkan hujan, maka setiap pementasan selalu disertai seremonial keagamaan dan disertai dengan berbagai upakara/banten. Pada umumnya setiap pementasan seni yang disertai dengan ritual, digolongkan sebagai sebuah tari sakral. Dan setiap tari/seni sakral biasanya dipentaskan di tempat-tempat suci dan di areal tertentu dari tempat suci tersebut. Misalnya di jaba tengah (madya) atau di jeroan (areal utama). Namun, pementasan Gebug Ende tidak demikian. Pementasan Gebug Ende berbeda dengan tari sakral yang lain. Permainan atau seni ini dapat dipentaskan di mana saja di kawasan wilayah desa adat Patas. Selama ini tempat pementasan Gebug Ende di desa Patas berpindah-pindah dari satu tempat ke tempat lain. Dasar pemilihan tempat hanya didasarkan pada kondisi areal. Apabila arealnya datar dan lebar/luas, maka dapat digunakan sebagai tempat, pementasan tradisi Gebug Ende ini. Areal yang digunakan sebagai tempat pementasan dibagi menjadi dua dengan pembatas tali rapia dan bambu. Sebagian areal untuk permainan Gebug Ende dan sebagian areal untuk para penonton. Demikian pula dengan ketentuan waktu, tidak selalu dikaitkan dengan pedewasan (wariga) atau hari baik. Pada umumnya pementasan ini dilaksanakan setelah para petani menanam jagung dan musimnya kemarau dan para petani sepakat pada hari tertentu untuk memohon hujan kepada Hyang Widhi, maka akan dilaksanakan pementasan Gebug Ende ini. Hal inilah yang menyebabkan sampai saat ini ada pendapat yang kontradiksi di kalangan masyarakat apakah Gebug Ende ini tergolong sakral atau Profan. Walaupun demikian para petani tetap mensakralkan pementasan Gebug Ende ini.

\section{Pakaian dan Perlengkapan Peserta Gebug Ende}

Para pemain Gebug Ende menggunakan pakaian yang sangat sederhana, tidak seperti tari Bali pada umumnya. Tari Bali umumnya menggunakan pakaian atau kostum yang bersifat khusus seperti ada gelungan, bapang, gelang kana, saput, oncer dan sebagainya. Warna pakaian serba keras seperti merah, kuning, hijau dan dipadu dengan gambar-gambar yang berwarna keemasan sehingga para penari tampak anggun, berwibawa dan angker. Gebug Ende hanya menggunakan : 1). Destarlikat kepala berwarna merah sebagai lambang keberanian, 2). Kain/kamen, dipakai dengan mebulet ginting dan 3). Saput poleng, (hitam putih) sebagai lambang rwa bhineda (baik buruk).

Para peserta Gebug Ende juga menggunakan alat-alat yang sederhana. Oleh karena permainan ini melambangkan prajurit yang sedang berperang, maka alat-alat yang dibawa para pemain tentu peralatan berupa senjata untuk menyerang 
lawan dan penangkis serangan lawan. Para pemain hanya membawa rotan (penyalin) untuk memukul lawan dan tameng/Ende untuk menangkis serangan lawan. Pada saat pertandingan dimulai dipimpin oleh seorang pemimpin pertandingan yang disebut pakembar. Untuk kesemarakan jalannya permainan, maka pertandingan ini diikuti dengan tabuh yang sederhana yang terdiri dari beberapa bagian gambelan Bali, antara lain: sepasang kendang cedugan, cengceng rincik, empat buah reong, seruling, dan kempul.

\section{Tata Cara Pementasan Gebug Ende}

Sebuah permainan dan pertandingan tentu ada aturan dan tata cara yang harus dipatuhi oleh para peserta. Demikian pula dengan pementasan Gebug Ende ini, ada beberapa aturan yang harus dipatuhi oleh seorang peserta. Adapun tatacara pementasan Gebug Ende sebagai berikut.

Gebug Ende dipimpin oleh seorang pemimpin pertandingan yang dikenal dengan sebutan saya. Saya inilah yang mengatur permainan, seperti memulai permainan, memisahkan pemain apabila dipandang tidak sportif dan mengakhiri pertandingan. Sebelum pertandingan dimulai diawali dengan upacara keagamaan yang dipimpin oleh seorang pemangku kahyangan tiga. Setelah itu saya mengumumkan aturan dan tata tertib permaian kepada para peserta. Selanjutnya, sebelum permainan dimulai ditentukan pasangan-pasangan yang akan pentas dan sekaligus ditabuhnya gambelan yang akan mengiringi permainan Gebug Ende. Dengan dimulainya tetabuhan gambelan, sebagai pertanda bahwa pertandingan segera dimainkan. Biasanya sebelum para peserta pertandingan dimulai, saye yang terlebih dahulu, menunjukkan dan meragakan tarian Gebug Ende, setelah itu baru para peserta yang berlaga sesuai dengan nomor urut yang didapat.

Aturan pokok yang harus dipatuhi oleh para peserta adalah peserta tidak boleh memukul dari pinggang ke bawah. Artinnya, para peserta dilarang memukul pinggang, perut, paha dan kaki. Bagian tubuh yang boleh diserang di atas pinggang ke atas seperti punggung, tangan, lengan dan kepala.

\section{Simpulan dan Saran}

Berdasarkan uraian di atas dapat disimpulkan dan diberikan beberapa saran sebagai berikut.

\section{Simpulan}

1. Lara belakang pementasan tradisi Gebug Ende pada upacara memohon hujan adalah sejarah kemenangan prajurit-prajurit Karangasem yang berasal dari desa Seraya berkat adanya hujan lebat pada saat perang melawan prajurit Seleparang, sehingga setiap kekeringan/kemarau, dilaksanakan ritual mememohon hujan selalu disertai dengan permainan perang-perangan yang disebut Gebug Ende.

2. Upakara yang mengiringi pementasan tradisi Gebug Ende di desa Patas, sangat sederhana, yakni berupa sesajen atau banten. Banten yang digunakan sangat sederhana terdiri dari beberapa jenis banten saja, yaitu canang raka, daksina, dan segehan nasi hitam putih. 
3. Tempat pementasan tradisi Gebug Ende tidak harus mencari tempat suci, melainkan tepat atau areal yang luas dan datar yang berada di wilayah atau kawasan desa Patas. Oleh karena itu, tempatnya bisa berpindah-pindah.

4. Pakaian dan perlengkapan peserta Gebug Ende di desa Patas hanya menggunakan :1). Destar/ikat kepala berwarna merah sebagai lambang keberanian, 2). Kain/kamen, dipakai dengan mebulet ginting dan 3). Saput poleng, (hitam putih) sebagai lambang rwa bhineda (baik buruk).

5. Tata cara pementasan tradisi Gebug Ende di desa Patas dipimpin oleh seorang saya, yang diawali dengan ritual keagamaan. Selanjutnya saya menyampai aturan permainan, yakni peserta tidak boleh memukul dari pinggang ke bawah. Kemudian saya menetapkan pasangan-pasangan yang akan pentas. Setelah tabuh dibunyikan, saya meragakan tari Gebug Ende dan selajutnya permainan dimulai sesuai dengan urutan yang telah ditentukan.

\section{Saran}

Berdasarkan simpulan di atas, maka penulis memberikan beberapa saran sebagai berikut.

1. Tradisi Gebug Ende ini sebuah permainan, apakah termasuk propan atau sakral yang di dalamnya mengandung unsur kekerasan karena saling serang antar peserta, maka disarankan kepada saya, agar bersifat bijak dalam memimpin permainan sehingga tidak membawa dampak negatif terhadap tradisi yang padanya mulia dan mengembirakan menjadi pemicu terjadinya konflik antar penduduk desa Patas.

2. Tradisi Gebug Ende sudah dijadikan aekon atau lambang desa Patas, maka disarankan kepada masyarakat untuk melaksanakan secara berkesinambungan setiap musim kemarau sebab bentuk tradisi ini adalah salah satu bentuk budaya yang unik yang dimiliki Kabupaten Buleleng.

\section{DAFTAR PUSTAKA}

Agus Salim, (Penyunting) (2001). Teori dan Paradigma Penelitian Sosial (dari Denzin Guba dan Penerapannya), Penerbit: PT. Tiara Wacana Yogyakarta.

Alwasilah, A. Chaedar (2002). Pokoknya Kualitatif, Dasar-dasar Merancang dan Melakukan Penelitian Kualitatif, Penerbit: Pt Dunia Pustaka Jaya dan Pusat Studi Sunda, Jakarta.

Bakker, Dr. Anton \& Drs. Achmad Charris Zubair (1994) Metodelogi Penelitian Filsafat, Penerbit: Kanisius, Yogyakarta.

Bryan \& Jurner (2006). Agama \& Teori Sosial, Penerbit: IRCiSod, Yogyakarta.

Drama Putra, I Nyoman (Editor). (2004). Bali Menuju Jagadhita: Aneka Perspektif, Penerbit: Pustaka Balipost, Denpasar.

Dasim Mathar, MA. DR. H. Moch. (2005). Sejarah, Teologi dan Etika, Agamaagama. Penerbit: Dian/Interfidei, Yogyakarta. 
Gunadha, M.Si, Prof. Dr. Ida Bagus (2008-2009), Pemberdayaan Desa Pakraman, Sebagai Strategi Kebertahanan Adat, Budaya dan Agama Hindu Bali. Pembinaan Desa Pekraman, Kerja sama UNHI Denpasar \& Kanwil Departemen Agama Propinsi Bali.

Kutha Ratna, SU. Prof. Dr. Nyoman (2010) Metodelogi Penelitian Kajian Budaya dan IImu Sosial Humaniora pada Umumnya, Penerbit: Pustaka Pelajar, Yogyakarta.

Nyoka (1990) Sejarah Bali, Penerbit: Toko Buku Ria, Denpasar.

Singgin Wikarman, Drs. I Nyoman, (1998). Sanggah Kamulan, Fungsi dan Pengertiannya, Penerbit: Paramita, Surabaya.

Simpen, AB. Wayan (1986). Adat Kuna, Catur Desa (Tiga Wasa, Sidatapa, Pedawa, Cempaga). Penerbit: -

Soebandi, Ktut (2008). Riwayat Merajan di Bali, Penerbit: CV. Kayumas Agung, Denpasar.

Soebandi, Ktut (1981). Pura Kawitan/Padharman dan Panyungsungan Jagat, Penerbit: CV. Kayumas, Denpasar.

Soebandi, Ktut (1983). Sejarah Pembangunan Pura-pura di Bali, Penerbit: CV. Kayumas, Denpasar.

Suasthawa Dharmayuda, SH. I Made (1995). Kebudayaan Bali, Pra Hindu, Masa Hindu dan Pasca Hindu, Penerbit: CV. Kayumas Agung, Denpasar.

Sudarsana,MBA.MM. Drs. I.B.Putu (2000). Ajaran Agama Hindu Manifestasi Sang Hyang Widhi, Penerbit: Yayasan Dharma Acarya, Percetakan Mandara sastra, Denpasar.

Sugeng Pujilaksono. (2006). Petualangan Antropologi, Sebuah Pengantar IImu Antropologi, Pnerbit: UPT. Penerbitan Universitas Muhammadiyah, Malang.

Sutaba, I Made (1980) Prasejarah Bali, Penerbit: B.U Yayasan Purbakala Bali.

Tantera Keramas, Prof. Dr. Dewa Made (2008) Metode Penelitian Kwalitatif dalam IImu Agama dan Kebudayaan; Penerbit: Paramita, Surabaya.

Team Penyusun, (1993). Pedoman Pembinaan Umat Hindu Dharma Indonesia, Penerbit: Upada Sastra, Denpasar.

Team Penyusun, (1985/1986). Sejarah Perkembangan Agama Hindu di Bali, Penerbit: Proyek Penyuluhan Agama dan Penerbitan Buku Agama (1985/1986), Pemerintah Daerah Tingkat I Bali, Denpasar.

Tim Penyusun, (2005). Pedoman Pembinaan Lembaga Keagamaan Hindu, Penerbit: Paramita, Surabaya.

Triguna, Ida Bagus Gede Yudha, (2001). Mengapa Bali Unik; Penerbit: Pustaka Jurnal Keluarga, Jakarta. (2001). Strategi Hindu; Penerbit: Pustaka Jurnal Keluarga, Jakarta. 
Pendit, Nyoman S. Sri Chandrasekharendra Saraswati (1993). Aspek-aspek Agama Hindu, Seputar Weda dan Kebajikan. Penerbit: Pustaka Manik Geni, Jakarta.

Pendit, Nyoman S. (1995). Hindu Dalam Tafsir Modern, Penerbit : Yayasan Dharma Naradha, Denpasar.

Purwita, Drs. Ida bagus Putu, (1984). Desa Adat dan Banjar di Bali, Penerbit: Percetakan Kawi Sastra, Denpas 
Jurnal Widya Sastra Pendidikan Agama Hindu, Vol. 2, No. 12019

e-ISSN : 2656-7466, p-ISSN : 1907-9559 